IZA DP No. 8279

Between Light and Shadow: Informality in the Russian Labour Market

Vladimir Gimpelson

Rostislav Kapeliushnikov

June 2014 


\title{
Between Light and Shadow: Informality in the Russian Labour Market
}

\author{
Vladimir Gimpelson \\ HSE and IZA \\ Rostislav Kapeliushnikov \\ HSE and IMEMO
}

Discussion Paper No. 8279

June 2014

IZA

P.O. Box 7240

53072 Bonn

Germany

Phone: +49-228-3894-0

Fax: +49-228-3894-180

E-mail: iza@iza.org

Any opinions expressed here are those of the author(s) and not those of IZA. Research published in this series may include views on policy, but the institute itself takes no institutional policy positions. The IZA research network is committed to the IZA Guiding Principles of Research Integrity.

The Institute for the Study of Labor (IZA) in Bonn is a local and virtual international research center and a place of communication between science, politics and business. IZA is an independent nonprofit organization supported by Deutsche Post Foundation. The center is associated with the University of Bonn and offers a stimulating research environment through its international network, workshops and conferences, data service, project support, research visits and doctoral program. IZA engages in (i) original and internationally competitive research in all fields of labor economics, (ii) development of policy concepts, and (iii) dissemination of research results and concepts to the interested public.

IZA Discussion Papers often represent preliminary work and are circulated to encourage discussion. Citation of such a paper should account for its provisional character. A revised version may be available directly from the author. 
IZA Discussion Paper No. 8279

June 2014

\section{ABSTRACT}

\section{Between Light and Shadow: Informality in the Russian Labour Market}

Economic growth in Russia in the first decade of this century almost doubled the country's GDP but was accompanied by substantial reallocation of labor to the unregulated sector while formal employment was on gradual decline. The paper overviews evolution of the Russian labour market during the period of 2000-10 and discusses most general implications of informality to employment and earnings as well as the associated political economy challenges and consequences.

JEL Classification: J31, J40, P2

Keywords: informal labour market, employment, Russia

Corresponding author:

Vladimir Gimpelson

Higher School of Economics

Department of Applied Economics

Room 114, Building 2

4 Slavyanskaya Ploschad

Moscow

Russia

E-mail: vladim@hse.ru 


\section{Introduction ${ }^{1}$}

Widespread and rising labour market informality emerges as a salient feature of many transition economies (Packard et al. 2012). Its persistence and proliferation have multiple causes, including a structural shift towards the small-scale service sector, poor governance and often unfriendly institutions (the "grabbing hand" of the state), increasing competition and growing costs for formal businesses, weak unemployment protection, etc. Many individuals and households are directly or indirectly affected by the rise in informality and many others appear to be at risk of that. Though the particular reasons for becoming informal and the implications of that vary greatly, one common feature persists. This economic activity unfolds in the shadow of regulations and out of reach of state institutions, thus raising questions concerning both the quality of these jobs and the quality of the state.

The purpose of this paper is to summarise our knowledge on informality in the Russian labour market and to embed it into a more general political-economic framework linking it to particular institutional developments. The main question can be formulated in the following way: how did informality in the Russian labour market evolve, and what are its political implications?

Russia presents an interesting case for studying informality since it differs from most other informality-ridden countries in several important aspects. First, it is a nonagricultural economy (the agricultural share of employment is under 10 per cent and the share of rural population is around 25 per cent). Second, most of the informal employment consists of hired labour, not of self-employed persons, as is often the case in the developing world. Third, the rise in informality can largely be attributed to a protracted transition towards a market economy rather than by rural-urban migration accompanying underdevelopment. Finally, informal workers in Russia possess a relatively high level of education compared to those in other countries.

The paper is organized as follows. Section 2 provides a brief overview of recent labour market trends and describes the institutional framework in Russia. In section 3 we use several different data sources to look at the evolution of informal employment. We also

${ }^{1}$ The paper was written as a draft chapter for the book "The Challenges for the Russia’s Politicized Economic System”. Support from the Basic Research Program of the National Research University Higher School of Economics is gratefully acknowledged. The authors thank Susanne Oxenstierna and Fabian Slonimczyk. 
investigate the main determinants of informality. Section 4 looks at the issue of labour market segmentation. Is the Russian labour market segmented, with informality forming a special segment? We address this question by exploring mobility patterns and the consequences of informality on earnings. Section 5 discusses political challenges concerning informality. Conclusions summarise our findings.

\section{Labour Market Developments and the Institutional Setting in Russia}

Going informal is often considered a reaction to the difficulties in getting a formal job when support to unemployed individuals is meagre. Since access to formal positions for wage and salary workers depends on labour market tightness, in this section we provide a short overview of the major developments at the macro level over the last decade. Since informality is often related to rigidities in the labour market, we also describe here in brief its particular country-specific institutional properties.

\subsection{Main labour market developments}

Soon after the financial crisis of 1998, the Russian unemployment rate reached an all time record high of 14.6 per cent. However, in early 1999, unemployment started to decline rapidly as a reaction to the economy's return to a path of growth. Boosted by the strong devaluation of the national currency and supported by the rise in world oil prices, that year the Russian economy entered a period of fast growth that lasted until 2008. Unemployment declined gradually and fell under 6 per cent by mid-2008.

Meanwhile, the economic recovery was also reflected in other labour market indicators. The employment to population ratio increased by $5 \mathrm{pp}$, accumulated wage arrears dwindled, the incidence of underemployment was reduced, and the number of annual hours worked increased. Hiring rates stayed high and were positively correlated with vacancy rates. But the most impressive labour market development was real wage growth, which, according to Rosstat, was between 12 and 15 per cent per annum over the period. As a result, within less than a decade the Russian labour market's performance changed radically for the better.

A closer look shows, however, a more complex picture. Protected employment in all types of firms decreased from 52 to about 48 million, or by 7-8 per cent, while the proportion of workers in temporary, casual and informal sector jobs was on the rise. In other words, the fraction of workers employed in various "bad" jobs rose continuously 
in spite of robust macro-economic performance (Non-standard Employment in the Russian Economy 2007; Lehmann et al. 2011).

The economic crisis that erupted in 2008-09 caused the GDP to fall by 8 per cent in 2009 but did not have immediate measurable consequences in the labour market. There was little actual overnight downsizing in 2008. In 2009, the unemployment rate reached 8.3 per cent and other labour market indicators began to deteriorate as well: real wage growth turned slightly negative, wage arrears (though quite modest) reappeared, and under-employment was on the rise again. Nevertheless, this grim period was short and all indicators started to improve soon, signalling that the major threats (in the form of unemployment or underemployment as they were seen by the Russian Government) had been left behind. In the following years of 2011-13 the unemployment rate slid further, down to historical lows of 5.5 per cent. This was associated with relatively stable total employment but continuing gradual reallocation of labour from the formal sector to broadly-defined informal or semiformal jobs. This reallocation can be interpreted as a sign of the trade-off between unemployment and informality, with the priority given to the latter.

\subsection{Institutional Setting}

Informality has multiple causes. It is often considered a direct consequence of excessively rigid labour market institutions. The minimum wage, if set too high, can push low-skilled workers out of formal jobs. Excessively strict employment protection legislation (EPL), collective bargaining pressures, high labour taxes and a high wage premium in the public sector are all likely to suppress labour demand and job creation in the formal sector. As a result, workers can be kept out of formal employment. If, at the same time, unemployment benefits are low and/or difficult to obtain, workers can easily end up in informal jobs, as they provide the only alternative option available.

Is the Russian labour market excessively rigid, thus raising the likelihood of informality? Not at all. The institutional setting during the transition years did not hinder wage flexibility and accommodated very strong external shocks, though through non-conventional price adjustment (OECD 2011; Gimpelson and Kapeliushnikov 2013). During most of the transition period, the minimum wage was fixed at a level that was hardly binding for the majority of firms. Its ratio to the average wage was below 10 
per cent during most of the period. Adjustments were irregular, lagged far behind inflation, and had little effect on relative earnings.

The unemployment benefits (UB) level can also affect informality (Margolis et al., 2012; Vodopivec, 2013; Bosch, Esteban-Pretel, 2013). If set too high (relative to median or average wage), it pushes reservation wages up, thus causing a reduction in employment. Some of those displaced can go into informality but are more likely to transit into unemployment. If UB are low, the unemployed state is not a viable option for those in need of income. In this case, informal economic activity can play a buffering role as an effective alternative to non-employment. In Russia, the average UB to wage ratio reached a peak of 30 per cent in 1998 but gradually eroded thereafter, ultimately dipping below 8 per cent. This is a very low level compared to other countries $^{2}$ and can play an effective role (given also the chronic lack of decent job vacancies at the disposal of the Public Employment Service (PES)) in making informality an alternative option instead of lowering job search costs for formal job seekers.

Employment protection legislation (EPL) is another important pillar. Strict EPL protects insiders from job loss. By doing that, it restricts outflow from formal jobs but also discourages new job creation. In theory, therefore, it may inhibit labour market mobility, including flows in both directions between formal and informal jobs. Regardless of how we estimate nominal stringency of the Russian EPL, most experts agree that its enforcement is far from perfect. Due to poor enforcement, the EPL per se is unlikely to be a valid cause for expansion of the informal employment. However, given the uneven and incomplete enforcement, firms and workers may choose the optimal degree of informality, trading off its costs and potential benefits.

Taxation of labour is still another standard candidate when the explanation of informality expansion in transition countries is needed (Packard et al. 2012; Slonimczyk, 2012). Creating a tax wedge, it decreases labour demand for taxpaying firms. In 2001, tax reform that drastically reduced taxation levels and simplified the process of filing taxes was introduced. The pre-reform progressive personal income tax

\footnotetext{
2 The unemployment benefit replacement ratio in the EU-15 is close to 50 per cent and in the Central and Eastern European countries is around 25 per cent (Lehmann and Muravev 2011).
} 
rates were replaced by a flat and low rate of 13 per cent. Payroll taxes were also affected. Starting in 2001, social contributions were unified into a single and smaller social tax with a regressive scale. ${ }^{3}$

As this short overview suggests, Russian labour market institutions do not appear as an important source of rigidity causing informality. On the contrary, the trade-off between employment and wages was on every occasion solved in favour of keeping employment stable, though some institutional decisions might matter. However, there were other factors outside the labour market per se at work that could suppress labour demand and explain the expansion of informal employment. Most important among them were the notoriously unfriendly business climate and low enforcement capabilities of the Russian state. According to the World Bank 'Doing Business', Russia is among the lowest ranked countries. A poor business climate reduces economic activity, discourages new investments, and deters entry and growth of formal firms, which reduces labour demand in the formal sector and thus makes informality the second best option for job seekers.

\section{The Evolution of Informality}

Relationships between GDP growth and labour market informality are ambiguous. If the economic growth is associated with intensive employment generation in the formal sector, informality can shrink as long as informal workers land in formal positions. To get this positive story, one needs an institutional environment conducive to massive job creation. However, it is not difficult to think of situations when the rapid economic growth can itself speed up informality. Such an outcome is likely, for example, if the growth is driven largely by micro-entrepreneurship and small-scale services prone to informality. Another example assumes that the aggregate growth in the country is driven by the formal sector but its gains stimulate informal economic activity. If massive injection of incoming petro-dollars is split over the population and generates growing demand for personal services and individual home construction, this may easily translate into informality given the generally unfriendly environment for conducting business activity with full obedience of formal rules.

\footnotetext{
${ }^{3}$ In 2010, the rates for social contributions were raised again.
} 


\subsection{The Evolution of Informal Employment}

Labour market informality can be measured in various ways and by using different data sources. The estimates usually vary depending on measurement methodology and available data sets, though we expect them to provide a largely coherent picture.

The Russian official statistics (Rosstat) applies a version of the productivity based definition (Hussmans 2004), which links informality to characteristics of enterprises and not of particular jobs. Using the standard SNA (System of National Accounts) divisions by institutional sectors, we can say that the Rosstat definition classifies all those who work in entities related to "the corporate sector" or to "the government sector" as formally employed, while all those who work in household-related productive units are considered informally employed whether they are registered with tax authorities or social protection agencies or not. Put another way, "formal workers" (in the Rosstat definition) are employed by organizations - legal entities -- while "informal workers" are those who work outside of them. This definition of informality encompasses all the self-employed, as well as wage and salary workers employed by unincorporated microbusinesses or by private individuals outside the formal sector, but it largely overlooks informal workers in formal enterprises.

The first and most straightforward approach to measuring employment in the informal sector is to use the labour force survey data available for the period 1999-2013. The second one relies on the same definition of informality but measures a different way, based on regular enterprise statistics. It estimates the difference between the total employment and the employment in all firms and organizations. The latter component can be obtained from the regularly updated statistical registry covering all firms officially registered firms with legal entities. This residual measure (total employment minus employment in all legal entities) encompasses self-employment (both with and without formal registration), workers hired by non-incorporated individual entrepreneurs or households, and family workers, while again also excluding informal workers in formal enterprises. The rationale for considering these groups as working informally (or semi-formally) is that, even if formally registered, they are not covered by standard labour, social security, accounting and tax legislation. These regulations, if even applied at all, are enforced in a simplified and truncated form with multiple exemptions. This residual approach provides a broader but less conventional measure of informality. 
According to the first approach, informal workers made up about one-fifth of the total employment in 2013, while the second approach estimate is closer to one-third. The gap between the two arises due to the different methodologies of measurement. The LFS may not identify all of those who work in small non-incorporated or fully unregistered businesses as informal workers (if such LFS respondents say that they are employed by “a firm”). Having accounted for this omission, we may get a higher LFS measure and narrower gap. In its turn, the residual approach may misidentify some fully formal workers, inflating the estimate. But neither way of measurement fully captures those working in formal firms but without a written contract.

However, the growth rates for both measures are almost identical, as Figure 1 suggests. It presents the general trends in informality and economic growth over the period. The GDP grew over the period 1998-2008 by an impressive 80 per cent. But did it pull workers from informal jobs? Quite the opposite! Informality by either definition increased at about the same speed, and by the end of the period was about 60 per cent higher than in the beginning. Meanwhile, the change in total employment was very small, while the regulated and protected employment in all types of firms and organizations even went down. In sum, a large and growing fraction of employment generation happened outside the regulated sector.

The economic crisis of 2008-09 brought a short break in the trend and caused a significant fall by around 8 per cent in GDP. This was not immediately reflected in total employment. However, the informal sector in the LFS-based definition accepted by Rosstat suffered a visible negative shock with a one year lag. Employment in the residual (outside firms) sector was on the rise during the whole period, with some slowdown in 2006-2008. Figure 1 shows a divergence between the paths followed by the informal employment (according to the LFS-based and the residual-based definitions) in 2009-10. While the former shrank (mostly due to a decrease in the number of dependent wage workers), the latter kept growing. Whether this fall in informality was a temporal statistical artefact or reflected the real phenomenon is not easy to determine. However, in 2011-13 the informal employment following the LFSbased definition returned to its pre-crisis peak.

Figure 1 presents the hypothesis that during this period there was a significant reallocation of workers from the regulated formal to the unregulated informal sector. Figure 2 illustrates the structure of this reallocation in 2000-12. The formal sector 
reduced its workforce during this period by almost 5 million individuals. This contraction was (more than) compensated for by the expansion of the unregulated (noncorporate) sector. In total, the latter gained over 7.5 million workers. Under an extreme assumption, that informality were not a possible option, then the economy would have lost over 4 million jobs rather than gained around 3 million. The expansion of the unregulated sector occurred mostly in activities like trade, construction, and transportation. These industries are largely populated by micro-businesses and the selfemployed.

So far, we have discussed estimates based on official data. As official statistical agencies are usually not very strong in measuring informality, we may want to check these findings (and even expand them) by bringing in alternative data sources that can better serve this purpose. Such a source at hand is the Russian Longitudinal Monitoring Survey (RLMS-HSE) which is a reliable and representative household panel with various informality-related questions. ${ }^{4}$ It covers 2002-2012 using the consistent definition.

Fig. 3 and Fig. 4 present the evolution of informal employment according to the RLMS data. The great advantage of this source is a clear distinction among different forms of informal employment. We can differentiate all employed according to two criteria: formality/informality and self-employed/dependent workers. In addition, those involved in irregular informal activities and marginally attached to the labour market but occasionally doing some paid work constitute the fifth group of workers. As the figures show, the expansion of informal employment occurred almost exclusively in wage and salary positions. Self-employment fluctuated around its average level (around 4 per cent for males and 2.5 per cent for females), while the fraction of workers performing irregular or casual activities decreased. All of this corresponds to the Rosstat data.

In sum, various data sources estimate the informal sector employment within the range of 20-30 per cent. How does it look in cross-country comparisons? Perry (et al., 2007) provides approximate relationships between various measures of informality and country per capita GDP. According to them, the Russian GDP per capita corresponds to an informality level equalling 25-30 per cent. As we can see, the actual level is somewhat lower than that which one can follow from these comparisons. Of course, any

\footnotetext{
${ }^{4}$ More on RLMS see here: http://www.hse.ru/en/rlms/
} 
cross-country informality comparisons are very approximate and allow rough typology only. One can safely say that the level of informality in Russia is comparable to that observed in other Eastern European countries and Southern Europe but is significantly higher than that in the most advanced market economies. However, it would also be fair to say that Russian labour market informality is much more modest than in other BRIC countries and in most other emerging economies. Its current level does not pose a real worry right now but its fast increase is challenging. Most of the growth comes through hired employment, not self-employment. In this sense, the informality is not a form of early micro-entrepreneurship which can potentially be creative and productive.

\subsection{Informality and productivity}

If informal employment is less productive than formal employment, then the reallocation of labour into informality reduces growth and productivity. This also means that a growing fraction of the total labour force is being used less efficiently than if formal employment were higher. .

According to the System of National Accounts (SNA) data, the fraction of the Russian GDP produced by the informal sector decreased from about 15 to $7 \%$ during the period of 2002-11. Meanwhile, informal employment kept expanding, as we could see, as did the total number of hours worked in the sector. Trying to reconcile these two tendencies, we can say that the formal-informal productivity gap is large and tends to grow further. Unsurprisingly, productivity in the formal sector is much higher than in the informal sector (see Table 1).

Partially, this gap can be explained by the simple fact that household-based subsistence agriculture is very low producing, while at the same time quite popular. Many Russian households are involved in this type of activity, using primitive technologies and little human capital. If this produce is consumed within households and not intended for market sales, such activity is not considered income gaining employment (according to the standard ILO criteria). Then, including agriculture in estimates of formal-informal productivity comparisons is likely to inflate the gap. Exploiting the fact that almost all household -based production is concentrated within the agricultural sector, we can reestimate the difference including only non-agricultural economic activity. This adjustment produces a smaller gap of “only” about 3 times instead of 4-5 if agriculture 
is included. However, even in this case the productivity gap gradually gets larger over time, not smaller.

In any case, it is fair to argue that observed reallocation of jobs from the formal to the informal sector (or de-formalization of employment) slows down the aggregate productivity growth and, therefore, brings an additional challenge to the modernization of the economy.

\subsection{Who is more exposed to becoming informal?}

Even if the informality level is modest on average, for particular demographic groups it can be quite high. As Table 2 based on RLMS data shows, informal salaried work and irregular activities are most prevalent among young men and women with low levels of formal schooling. Informal entrepreneurship and self-employment, in contrast, are more common among middle age men with technical or university degrees. Informal work is concentrated in service, agricultural, and low-skilled occupations. Informal entrepreneurs are usually classified under managerial occupations.

An important issue is whether some age groups are more exposed to informality than others due to a sort of life cycle (age) effect. New labour market entrants are more likely to find jobs in the informal sector. Having accumulated some work experience they gain formal positions, and finally may move back into informality after (or close to) retirement. This pattern can potentially apply to every cohort. An alternative story is that some cohorts are more vulnerable to informality because they enter the labour market in the period when labour demand in the formal sector is low.

In order to examine the issue in more detail, we estimated a multinomial logit model (MNL) of sector choice with these and other variables as determinants of informal status (Gimpelson, Kapeliushnikov and Slonimczyk 2014). This exercise was conducted separately for males and females using the whole data pool for 2000-10. We explored whether the determinants of informality changed over time by estimating the MNL model separately for different sub periods. Among the most remarkable results, we find that the likelihood of informal wage and salary work go down with age. The risk of irregular activities, however, is not significantly different across age groups. Men with any formal education see the risk of casual work significantly reduced, but only technical and university degrees seem to affect informal wage work negatively. For 
females, education does not seem to significantly affect job types other than irregular activities. Finally, the groups where informality is more prevalent are in the service, agriculture and fishery activities, and in "unskilled" occupations.

Summing up, our findings are consistent with the existence of additional search frictions that individuals of young and old age are likely to face. Individuals with low human capital are also more likely to go informal. Finding the first good job appears to be tough and people might churn for some time between informal jobs as a second best opportunity. The same is true for preretirement and retirement age individuals. In addition, being a student or getting a pension decrease the reservation utility expected from formal employment.

\section{The Labour Market: Segmented or Integrated?}

This is a key question in the exploration and explanation of informality. One approach sees this sector as a kind of semi-isolated ghetto populated by bad jobs. It assumes that low educated and low-skilled workers enter the sector involuntarily and have limited exits to better employment, and are also overexploited and underpaid there. Much of the literature generated by the ILO follows this research paradigm (Kucera and Ronkolato 2008). Another view sees the labour market as integrated. According to it, workers chose their preferred sector of employment, voluntarily maximizing their expected utility (Maloney 2004). Therefore, emerging wage gaps are small if any, and can be explained by differences in non-wage job amenities. Meanwhile, cross-sector flows provide additional tests on segmentation and, if large, they point out the integrated nature of the labour market. These opposing views suggest ultimately different remedies.

Exploring what view on the Russian labour market is more convincing and better supported by data we look first at mobility and then at earnings.

Mobility patterns. We explore mobility patterns using two complementary approaches. First, we examine transition matrices linking different labour market states to analyze intensity and direction of labour market flows. Second, we estimate an MNL model that simultaneously controls for past labour market states and demographic and job characteristics. 
Jobs in the informal sector are typically considered less secure since they are not protected by regulations. This is well reflected in the shorter tenures and higher mobility of informal workers, though that is not sufficient proof for the segmentation hypothesis. They can be mobile in both ways across formality borders. Segmentation means that informal employment becomes an absorbing state with a limited exit. If the pool of informal workers is stagnant with little outflow, then we can expect a segmentation in the labour market. Significant flows but going largely into non-employment could also be considered a valid argument. On the contrary, the dynamic interchange between the formal and informal sectors would indicate that the labour market remains integrated without strong internal divisions. The picture becomes more complex if we consider the informal labour market as internally heterogeneous and multi-tiered. In this case, some informal workers are integrated with the formal sector while others are separated in absorbing dead-end jobs. This picture is consistent with the multi-tiered vision of the informal sector suggested by G. Fields (Fields 1990; 2009).

The informality in our data consists of three different sub-states: informal entrepreneurs, informal salary workers, and casual workers. We estimated conventional transition matrices linking origin and destination states for the period 2003-2010. Table 3 presents mobility between four aggregated labour market states (formal, informal, unemployed and not in the labour force) and Table 4 disaggregates the formal sector into formal salaried employment and formal self-employment, while the informal sector is broken down into informal salaried employment, informal self-employment and irregular informal activity.

The detailed look at conventional mobility measures calculated and averaged for the whole period of 2003-2010 shows that annually about 11 per cent of those in the formal sector left it moving to alternative states (the informal sector, unemployment or out of the labour force). The informal sector was the leading destination, with this outflow making about 6 per cent of the initial stock. These values are higher than those reported by Lehmann and Pignatti for the Ukraine, where most of those leaving the formal sector ended up in non-employment (Lehmann and Pignatti 2007). The differences are remarkable considering the multiple institutional and structural similarities between the two countries. If the informal sector is disaggregated, informal wage and salary employment emerge as the destination for 3.4 per cent of those leaving the sector of origin (formal salaried employment). 
If we take informal employment as the initial sector, about a quarter of workers in the stock ended up in formal salaried employment one year later, thus illustrating high mobility, while 56 per cent remained informal as before. At the same time, informal workers (compared to formal) faced much higher risks of losing employment. However, the probability of a return to employment was also high. About 30 per cent of unemployed and 11 per cent of inactive landed in formal jobs within one year. Migration from non-employment to any informal employment was also very buoyant, especially from unemployment. Informal jobs as destination were picked out by 22 per cent of all unemployed individuals. These rates were comparable to outflows from unemployment to formal employment.

The breakdown of informality by sub-states provides additional evidence that both salaried employment and irregular activities are actively involved in exchange with other labour market states, while informal self-employment interacts actively with formal self-employment.

High rates of exchange between formal and informal employment do not suggest that strong segmentation of these sectors is a likely outcome. However, informal workers face higher risks of becoming unemployed and (especially) inactive than formal workers do. Russian informal workers do not form a stagnant pool, and most of those entering the informal sector have good chances of getting out relatively soon.

In other words, the emerging general picture is mixed. On the one hand, counter flows between the formal and informal sectors are of comparable intensity; outflow from the formal sector to informality dominates over flows to non-employment; each third informally hired worker moves into the formal sector within a year; most unemployed and about half of economically inactive enter the formal sector avoiding informality as a transient state; any self-employment decreases risk of unemployment; formal and informal self-employment are involved in an intensive exchange. All this indicates that rigid barriers separating formal and informal jobs hardly exist.

On the other hand, the fact that employment growth in Russia was driven by the expansion in informality can be interpreted as clear evidence of the difficulties of entering the formal sector. These difficulties can be caused by depressed labour demand in the formal sector (weak job creation through setting up new firms as well as employment expansion in existing firms). Disposition of formal workers to move out 
was low, new vacancies in the formal sector were generated in limited quantities and were not easily accessed by outsiders; states of unemployment, inactivity, informal salaried employment and irregular informal activity are strongly connected by cross flows suggesting that informality emerges as a dead end state. These findings tend to suggest that the labour market is a segmented, not an integrated one.

The transition matrices show flows across sectors without conditioning on worker characteristics. The dynamic multinomial logit (MNL) model for sectoral choice controlling for lagged employment statuses suggests that any form of employment decreases the risk of non-employment in the next period. Second, any prior entrepreneurial experience increases the probability of both formal entrepreneurship and informal self-employment. One may speculate that both forms of entrepreneurship are not strictly separated and resemble communicating vessels. However, informal entrepreneurship also increases the relative risk of doing informal salaried work. Third, we find that the only status that significantly increases relative risks of irregular activities is irregular activities themselves. In general, these workers are marginally attached to the labour force, but such activities appear to be an entry point for informal entrepreneurship and, to a lesser extent, informal wage and salaried work. Finally, formal salaried workers are less inclined to any outward transition.

Summing up, our findings are consistent with Fields' idea of a two-tiered structure of the informal labour market (Fields 1990; 2009). On the one hand, informal selfemployment seems to be integrated with formal entrepreneurship, and there is some evidence that irregular activities and informal wage and salaried work sometimes lead to entrepreneurial activities. On the other hand, all informal types of employment are selfreproducing and are largely separated from the formal labour markets. The fact that workers obtaining formal salaried positions are less likely to move to any other type of job suggests that they assign a high value to formality and prefer it over alternatives.

Informal earnings. An alternative way for testing segmentation is to estimate the formal-informal wage gap. ${ }^{5}$ If segmentation is associated with persistent earnings differentials, the integrated labour market is unlikely to produce such gaps. How can formal and informal jobs be compared in terms of wages in the Russian case?

${ }^{5}$ The discussion on earnings is based on Gimpelson, Kapeliushnikov and Slonimczyk (2014). 
Fig. 5 and 6 (based on RLMS data) show the evolution of earnings in each form of employment for men and women respectively. The decade under consideration was characterized by a continuous increase in living standards in Russia. According to official statistics, in 2010 the average (official) real wage was 2.7 times higher than in 1998. Informal earnings also increased significantly, though the rate of growth varied across job types. In terms of relative rankings in remuneration, however, there was very little change.

Both male and female entrepreneurs have the highest earnings throughout the period. Not surprisingly, entrepreneurial income appears to be more volatile relative to other forms of employment. Salaried workers are one step below in the earnings distribution. These figures also suggest that formal status does not have a strong impact on earnings for wage and salary workers. Finally, individuals performing only casual or irregular activities are at the bottom of the earnings distribution.

One important factor affecting the distribution of earnings is the wide differences in average monthly hours worked across different employment types. Two points are worth emphasizing. First, one reason for higher earnings is simply that entrepreneurs work more hours per month. In particular, formal entrepreneurs work 20 per cent more hours than formal employees during the same reference period.

Second, workers performing irregular activities have very low hours. On average, individuals in this category work only around 20 hours per week. A simple calculation of an "hourly wage" puts irregular activities above wage and salary workers. As a result, workers performing irregular activities have median wages comparable to those of entrepreneurs.

Average earnings differentials across job types can reflect the non-random selection of skills and other productive characteristics into certain types of jobs. We estimated earnings regressions controlling for some of the factors that might affect earnings and be correlated with job type. The specification we used allowed for the effect of hours to vary across employment types; it also included the set of standard control variables and added year dummies. In order to partially remedy the potential bias of the pooled OLS estimator, we estimated the panel fixed effect (FE) model and the Hausman-Taylor (HT) type random effects models. 
Formal entrepreneurs appear to earn on average 36 per cent (males) and 56 per cent (females) higher earnings than formal wage workers, if other factors are kept constant. Informal entrepreneurship brings the same wage premium for males and only a slightly lower premium for women. Informal salary workers face only a small penalty relative to formal salaried workers. Finally, workers in casual and irregular activities are not on average paid less than formal salaried workers. This fact seems surprising, but it reflects the effect of short hours supplied by a worker in this type of employment.

The pooled OLS results suggest that formal entrepreneurs earn a relative premium. The alternative FE and HT models are more "sceptical" in this regard, denying that this group of income earners enjoy a potential advantage relative to others. The entrepreneurial premium emerges as much smaller in size and statistically insignificant.

If demand for working time is strongly constrained by employment type and workers would be happy to supply more hours than they do, then it would still be possible to find a positive and significant effect of formal and informal entrepreneurship relative to any salaried work. This is so in relation to the short duration of irregular activities as well.

Summing up the evidence on earnings across job types, it seems safe to say that any self-employment brings a statistically significant wage premium (compared to observationally similar formal wage workers) while informal salary workers are not significantly penalized given the number of working hours they supply. Male workers involved in informal irregular activity can even win in relative terms while female workers emerge as losers in these comparisons. These results are significantly driven by variation in hours actually worked across job types. As an additional test, this exercise does not provide strong support to the segmentation hypothesis but detects some signs of it. Given the clear trend to informality expansion, the risk of stronger segmentation in the mid-term future can hardly be dismissed.

\section{Informality as a systemic institutional failure}

The informality issue cannot be confined by or reduced to partial labour market imperfections. Its persistence raises a number of questions concerning more general relationships between citizens and the state. Still, modest incidence of the Russian informality and weak symptoms of labour market segmentation should not pacify, since the rate of increase in informality against the background of economic growth seems to 
be troubling, and signalling mounting dysfunctions. As (Saavedra and Tommasi 2007: 280) point out, 'dimensions and measures of informality are indeed a reflection of broader systemic failures'. Inferior productivity in informal jobs is one of the salient indicators.

Russian informality has a number of features which are characteristic of such failures. Among the most emblematic we see the following, though this list is far from complete:

1) Interaction between shrinking labour demand in the formal sector and low UB replacement ratios,

2) Distrust in the state and state institutions (police, judiciary, regulators, etc);

3) Incomplete and selective enforcement of formal regulations;

4) The erosion of the tax base which potentially leads to underproduction of public goods;

5) Exclusion from access to social protection and various public services;

6) Blurred borderlines between formal and informal activities.

It is easy to see that all of them are strongly interconnected and manifest different dimensions of the same complex phenomenon. "In other words, several aspects of informality are ultimately a reflection of the way individuals interact with the State and with each other - that is, of the degree of "formalization" and inclusiveness of each country's social contract (Saavedra and Tommasi 2007: 280). These interactions are shaped by various State-related incentives and constraints that reinforce each other. If individuals do not trust in the ability of the State to provide high-quality public goods including judicial and social protection to all fellow citizens, then incentives to pay taxes are seriously undermined. The erosion of the tax base leads to further underproduction of public goods including enforcement of regulations. Weaker institutional enforcement-related capacity kills incentives to follow formal rules, etc. We are likely to enter a vicious circle that is hard to exit. Informality becomes a deep-rooted social norm able to enforce and reproduce itself and expand into the larger population.

Multiple equilibria and dynamics of social norms. Individual participation in informal transactions (including participation in employment) is shaped by incentives and costs, on the one hand, and by social norms, on the other. Social norms can work as additional incentives or contributions to total costs. These norms themselves reflect the long-term evolution of informality and specify a particular path of dependence. If few firms or 
individuals work informally, because such work is considered illegitimate and is widely condemned, dominant social norms deter the expansion of informality at the given level of enforcement technology. One can call it a good equilibrium. However, if, for any reason, the numbers of informal workers or of informal firms in the economy tend to grow, the costs of being informal may decrease and the incentives for it may, on the contrary, increase. This change affects not only social norms (how the society sees these violators and whether it is ready to condemn and punish) but the institutional capacity of the State as well. The costs of monitoring go up, the likelihood of detection goes down, and ultimately the enforcement technology is likely to weaken. Gradually, it changes the ratio between formal and informal workers. After reaching a tipping point, this ratio moves towards predominantly informal relationships, which corresponds to a new (bad) equilibrium.

We can impose this simple framework on the Russian informality dynamics that were discussed earlier. The growing rate of informality is an outcome of two macro factors. The first relates to the demand for informal labour, the second constrains workers' choices on the labour market if they leave a job. As we could see, the demand constrained by an unfriendly business climate and inefficient regulations has been on permanent decline. Workers exiting the (formal) sector face limited (and shrinking) employment opportunities in the formal sector, while the unemployment benefits replacement ratio affecting unemployment as an alternative option remains extremely low. In this context, informal employment emerges as the second best incomegenerating option.

The path of dependence in the evolution of the Russian informality has multiple roots and various reasons. However, the Russian state made its own significant contribution in launching (or boosting) the process in the recent transitional years. Though the macroeconomic shocks were extremely strong, the formal safety net that could support the Russian population in coping with hardships remained weak and holey, and was not even considered an urgent policy priority. This sent the clear signal to everybody that survival should rely on available informal and personal resources. Widespread allocation of small land plots and reduction in official working hours conducted by the state at that time increased such resources people might have at their disposal and use as productive assets in their informal activities (Gimpelson and Kapeliushnikov 2007). 
Trust. This is another important ingredient in the complex web of social interactions. Lower trust in the state and state institutions undermines expectations of public goods. In other words, the lack of confidence undermines the social contract connecting citizens and the state, thus leading to even higher informality through creation of positive feedback loops. Ultimately, by opting for being informal, an individual seeks to exit the state-controlled space; she wants to avoid the regulations imposed by the government as well as the associated responsibility.

Aghion et al (2010) present a model explaining the co-evolution of distrust and regulations. They argue that government regulation is strongly and negatively correlated with trust. Distrust in society (including general distrust and distrust of economic agents to the state) leads to heavier government regulation, (since economic agents themselves are not able to coordinate efficiently) but corrupt and inefficient state bureaucrats generate even more distrust through their activity. Informality can also be a part of this multivariate equation. On the one hand, informality emerges as a reaction to distrust in the state that major economic agents express. On the other hand, it pushes the state to regulate (government officials often consider informality as a symptom of incomplete regulations that should be expanded) even more, and therefore leads to further regulative failures. We end up with even more regulation, but less trust and more informality. In this triangle, informality is an important element and may emerge as a positive one, since it functions as an adjustment buffer when regulation critically fails.

Of course, important caveats should apply to these arguments. Conventional interpretation of the social contract assumes that individuals and the state exchange tax contributions for the provision of public goods absolutely voluntarily and consciously. In the Russian context, this condition should be modified. All individuals regardless of their employment status are eligible for basic pension and free health care by law. This universal coverage is usually combined with a low level (in terms of quantity and quality) of this provision. At the same time, these goods are financed from oil and gas rent revenues, not by tax receipts. This has a few major implications: access to basic public goods is not conditional upon formal employment and personal contributions, individuals (tax payers) are alienated from the state and government bureaucrats are not accountable to taxpayers. All these properties are positively correlated to informality. 
Incomplete enforcement and blurred borderlines between formality and informality. The division of the Russian labour market into two distinct sectors is too simplified. In fact, formality and informality are intimately intertwined states and make a stretched continuum, not a black-white dichotomy. Though the formal sector is largely governed by formal regulations, it is also heavily contaminated by informality. Meanwhile, the informal sector is not 100 per cent ignorant of acting legislation. (Gimpelson and Kapeliushnikov 2014: 169) present estimates of compliance of labour legislation, according to which Russian formal workers estimate the level of compliance at 88 per cent, and informal workers at 59 per cent. Formal workers believe that on average 8.4 chapters (of total 10) of the Labour Code are fully enforced, while informal give 5.1 as the estimate. The difference is significant but the role of informality in the formal sector is also significant. These figures are simple averages, while the actual distributions of informal relationships in formal and informal jobs are more complex and largely overlaid.

Poor law compliance in Russia is clearly not a new phenomenon and has a long tradition in the country's history. As M. Saltykov-Tchedrin put it in the mid-XIX century, "the stringency of Russian laws is offset by their non-observance". He was not just a great writer but a vice-governor of one of the provinces as well and knew well what he was talking about. Non-observance of laws and rules is one of the key elements of the flexibility that allows the Russian labour market to adjust to shocks today and, therefore, to perform relatively well. Given the current trend to overregulation followed by the Russian government in all major spheres of life, such non-observance becomes a challenge and a well embedded property at the same time.

Weak enforcement (which reflects the low capacity of the state to implement its own decisions) concerns all major wage and employment regulations. As we discussed in another piece of work, wages are not paid on time and in full, the variable part of wage payments is often not fixed by a contract, working hours may be shorter than the bottom limit permitted by law or much longer than the upper limit, the minimum wage is not binding, firings are substituted by semi-voluntary resignations, just to mention a few examples. The systemic imitation of strong governance does not prevent the adjustment from proceeding beyond and despite formal rules. This may explain the puzzling association between stringent regulations (on paper) and remarkable flexibility (in practice) (Gimpelson and Kapeliushnikov 2013). 
Poor observance of the law is well recognized by all labour market agents, as illustrated by data from a specially organized survey conducted a few years ago. According to this survey, the proportion of enforcers believing that "employment protection legislation (EPL) observance does not pose any problem” is strikingly small. This opinion is shared by just 3 per cent of the judges, 8 per cent of the employers' representatives, and by 3 per cent of the trade union regional leaders that were surveyed. None of the surveyed labour inspectors or the public employment service top officers accepted this position. If measured on the 7-point scale with the maximum given to complete observance, the Russian regions vary from 2.3 to 5.0 points. Most of the averages are under 4 points, while the employers assign just a little more than that. Note that these estimates relate to the formal sector, while in the informal sector they could be much lower.

In the early 2000s, the Russian authorities announced far-reaching plans to bring "more law and order” into all areas of economic life, including the labour market. In the context of these measures, not paying wages on time became a serious crime punishable by imprisonment, for example. This helped to curb the wage arrears epidemic but brought little law obedience in other areas. On the contrary, firms began to seek "refuge” in less regulated and not so well-monitored areas.

Obviously, such extralegal (beyond the rules) adjustment creates an uneven playing field and generates uncertainty for firms and workers. (Gimpelson et al 2010) documents that in Russia EPL enforcement varies significantly across regions, localities, and firms. This paper argues that the variation in enforcement across regions is translated into a variation in labour market performance, if the endogenous nature of enforcement is accounted for. Stricter enforcement raises EPL costs, other things being equal, affecting employment negatively and unemployment positively. Inter alia, this implies that the EPL is stringent enough, if the formal regulations are thoroughly applied. The cost of this stringency would be in lower employment and higher unemployment than was actually observed. However, informality helps to absorb some of these enforcement-induced shocks.

The unhappy combination of ubiquitous informality, poor enforcement technology, high monitoring costs for the state, and low probability of detection is very conducive to further informality expansion, and can hardly be disregarded as one of the political challenges. 


\section{Conclusions}

The expansion of labour market informality poses a few political challenges, which are all intrinsically intertwined. We discuss some of them while understanding well that many important dimensions of the problem are left here untouched.

Though labour market informality in Russia is on the rise, it has not yet become a problem of the scale facing many Latin American countries. This, however, can hardly be a valid argument for ignoring it completely. Many Latin American countries have been trying to reduce informality, while Russia seems to be moving the opposite way. The rate at which informality is expanding says more about the problem than the current fraction of informal workers in total employment. If informality tends to crowd out formality, one can conclude that job creation in the formal sector faces tough constraints and barriers. As it appears, much of the adjustment in the Russian labour market comes from the informal sector, which is able to expand and react quickly, while the formal one emerges as over-regulated and semi-frozen. This makes the issue of job creation in formal and informal sectors both an economic and a political challenge. It is economic since it affects growth and productivity, and it is political since it relates to the whole set of institutional conditions within which firms are functioning.

The second challenge concerns the "quality" of informality. Our study suggests that wage opportunities in the Russian informal sector are by and large comparable to those in the formal. This - together with the fact of large cross-sectional flows - paints a picture of a rather integrated, not a strongly segmented, labour market. A better account of the non-wage characteristics of jobs would probably add benefits and gains to the formal sector in its competition with the informal, though this would hardly change the main conclusion. However, this relatively benevolent picture is not a given forever. If informality keeps expanding, then segmentation may become more emphasized, with stronger implications in terms of growing poverty and inequality. These implications are obviously not politically and socially neutral.

The third challenge relates to human capital. Modern economic growth is human capital based while informality is not a fertile ground for its accumulation and efficient utilization. Much lower productivity in informal jobs equals to underutilization of education and skills. If workers entering informal jobs are already well equipped with human capital, they face high risk that much of that will be in little demand. If they 
enter their working life earlier, with few skills, they are unlikely to acquire many more skills later on. Anyway, we are likely to get a growing fraction of the labour force stuck in a low human capital intensive economy.

Finally, the fourth challenge deals with the endogenous interaction of informality and regulations, which goes both ways. Since most regulations are introduced and enforced by the state, this challenge is directly political. Informality emerges as a direct reaction to regulatory failures when regulations are excessive while state enforcement capacity is low. In such situations, politicians are often prone to introduce even more regulations therefore contributing to further deformalisation. The vicious circle turns into a reality, while the chances for breaking it become slimmer.

\section{References}

Aghion P., Y. Algann, P. Cahuc, A. Shleifer (2010) 'Regulation and Distrust', The Quarterly Journal of Economics, 125 (3); 1015-49.

Bosch, M. and Esteban-Pretel, J. (2013) 'The labor market effects of introducing unemployment benefits in an economy with high informality', IDB working paper series 402.

Fields G. (1990) 'Labour Market Modelling and the Urban Informal Sector', in D. Turnham, B. Salome, A. Schwartz (eds) The Informal Sector Revisited, Paris: OECD.

Fields G. (2009) 'Segmented Labour Markets Models in Developing Countries', in Ross D., H. Kinkaid (eds.) The Oxford Handbook of Philosophy of Economics, CITY: Publisher.

Gimpelson V. and R. Kapeliushnikov, eds. (2007) 'Non-standard Employment in the Russian Economy’: Moscow: HSE Publishing House.

Gimpelson V. and Kapeliushnikov R. (2013) Labour Market Adjustment: Is Russia Different? // In M. Alexeev and S. Weber (eds.), The Oxford Handbook of the Russian Economy. Oxford: OUP.

Gimpelson V., Kapeliushnikov, R. and Lukianova, A. (2010) 'Stuck between Surplus and Shortage: Demand for Skills in Russian Industry', LABOUR (24), 3: 311-32. 
Gimpelson V. and Kapeliushnikov R., eds. (2014) In the Shadow of Regulation: Informality in the Russian Labour Market. Moscow: HSE Publishing House.

Gimpelson V, Kapeliushnikov R and Slonimczyk A (2014) Between Light and Shadow: Cross-Sectoral Mobility. // In Gimpelson V. and Kapeliushnikov R., eds. In the Shadow of Regulation: Informality in the Russian Labour Market. Moscow: HSE Publishing House.

Hussmanns R. (2004) 'Measuring the Informal Economy: From Employment in the Informal Sector to Informal Employment’, Bureau of Statistics Working Paper No. 53. Geneva: International Labour Office.

Kucera D. and L. Ronkolato (2008) 'Informal Employment: Two Contested Policy Issues’, International Labour Review, 147: 321-348.

Lehmann, H. and Muravyev A. (2011) "Labor Markets and Labor Market Institutions in Transition Economies," IZA Discussion Paper No. 5905, Institute for the Study of Labour (IZA).

Lehmann H. and Pignatti N. (2007) Informal Employment Relationships and Labour Market Segmentation in Transition Economies: Evidence from Ukraine. IZA Discussion Paper No. 3269. Bonn: IZA.

Lehmann H., T. Razzolini, and A. Zaiceva (2011). Job Separations and Informality in the Russian Labour Market. IZA Discussion Paper No. 6230. Bonn: IZA.

Maloney W. F. (1999) 'Does Informality Imply Segmentation in Urban Labor Markets? Evidence from Sectoral Transitions in Mexico', The World Bank Economic Review, 13: 275-302.

Maloney W.F. (2004). 'Informality Revisited', World Development, 32: 1159-1178.

Margolis D, L. Navarro, D. Robalino (2012). Unemployment Insurance, Job Search and Informal Employment. IZA Discussion Paper No. 6660. Bonn: IZA.

OECD (2012) 'Labour Market and Social Policy Review of the Russian Federation', Paris: OECD. 
Ostschepkov A. (2012) 'Minimum Wage and Informality', In Gimpelson V. and Kapeliushnikov R., ed. (2014). In the Shadow of Regulation: Informality in the Russian Labour Market. Moscow: HSE Publishing House.

Packard, T., J. Koettl, and C. Montenegro (2012) 'In From the Shadow: Integrating Europe’s Informal Labor', Washington DC: The World Bank.

Perry, G., W. Maloney, O. Arias, P. Fajnzylber, A. Mason, and J. Saavedra-Chanduvi (2007) 'Informality: Exit and Exclusion’, Washington DC: The World Bank.

Saavedra J., and M. Tommasi (2007) 'Informality, the State and the Social Contract in Latin America: A Preliminary Exploration’, International Labour Review, 146: 279-309

Slonimczyk F. (2012) 'The Effect of Taxation on Informal Employment: Evidence from the Russian Flat Tax Reform' In H. Lehmann, K. Tatsiramos (eds.), Informal Employment in Emerging and Transition Economies (Research in Labor Economics, 34: 55-99).

Vodopivec M. (2013) 'Introducing unemployment insurance to developing countries', IZA Journal of Labour Policy, 2 (1). 
Fig. 1: Employment and GDP Growth 1999-2011 (1999=100)

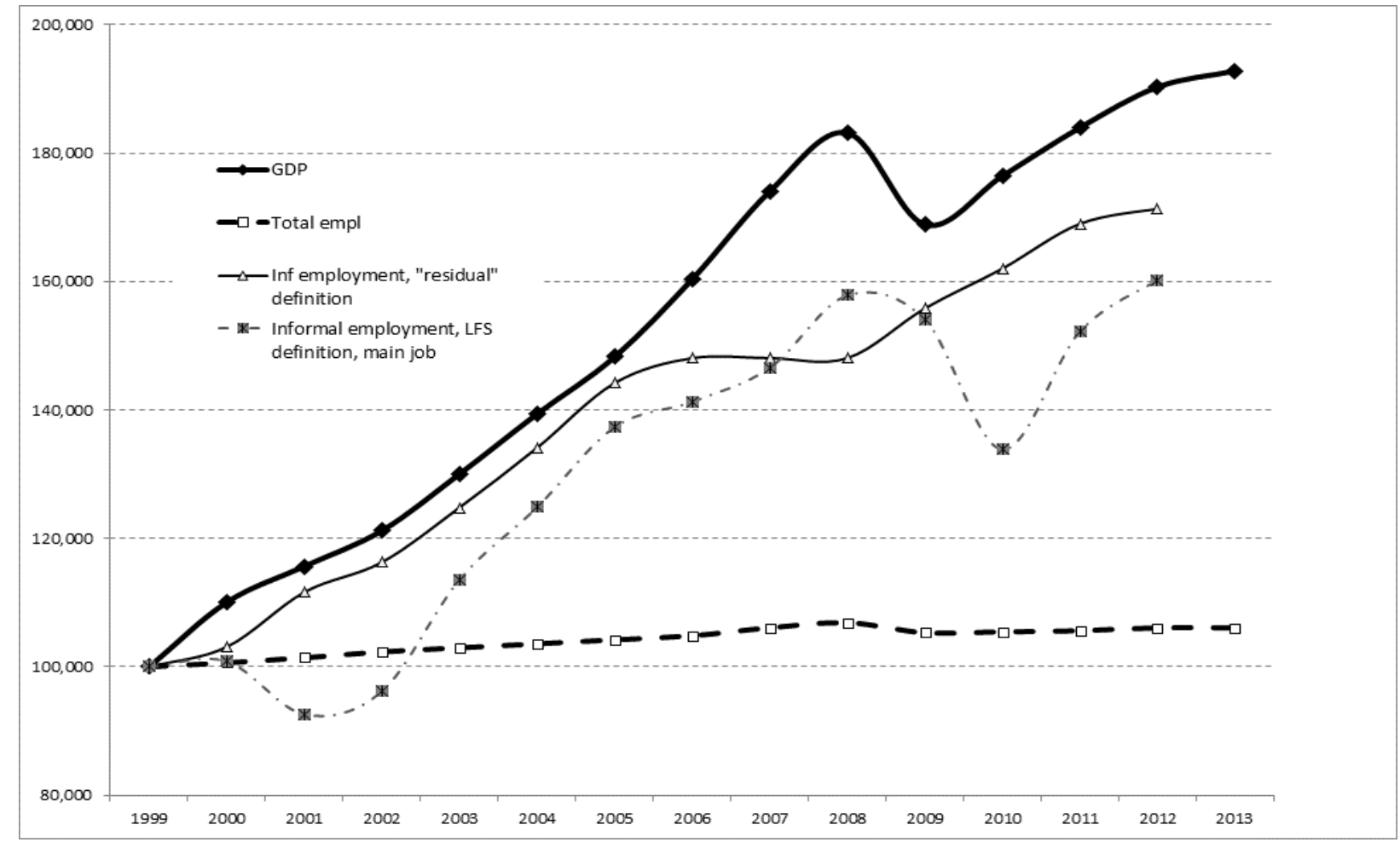

Source: Rosstat, the authors’ estimates

Fig. 2. Change in Total Employment, Formal and Informal Employment, 2000-2012, millions

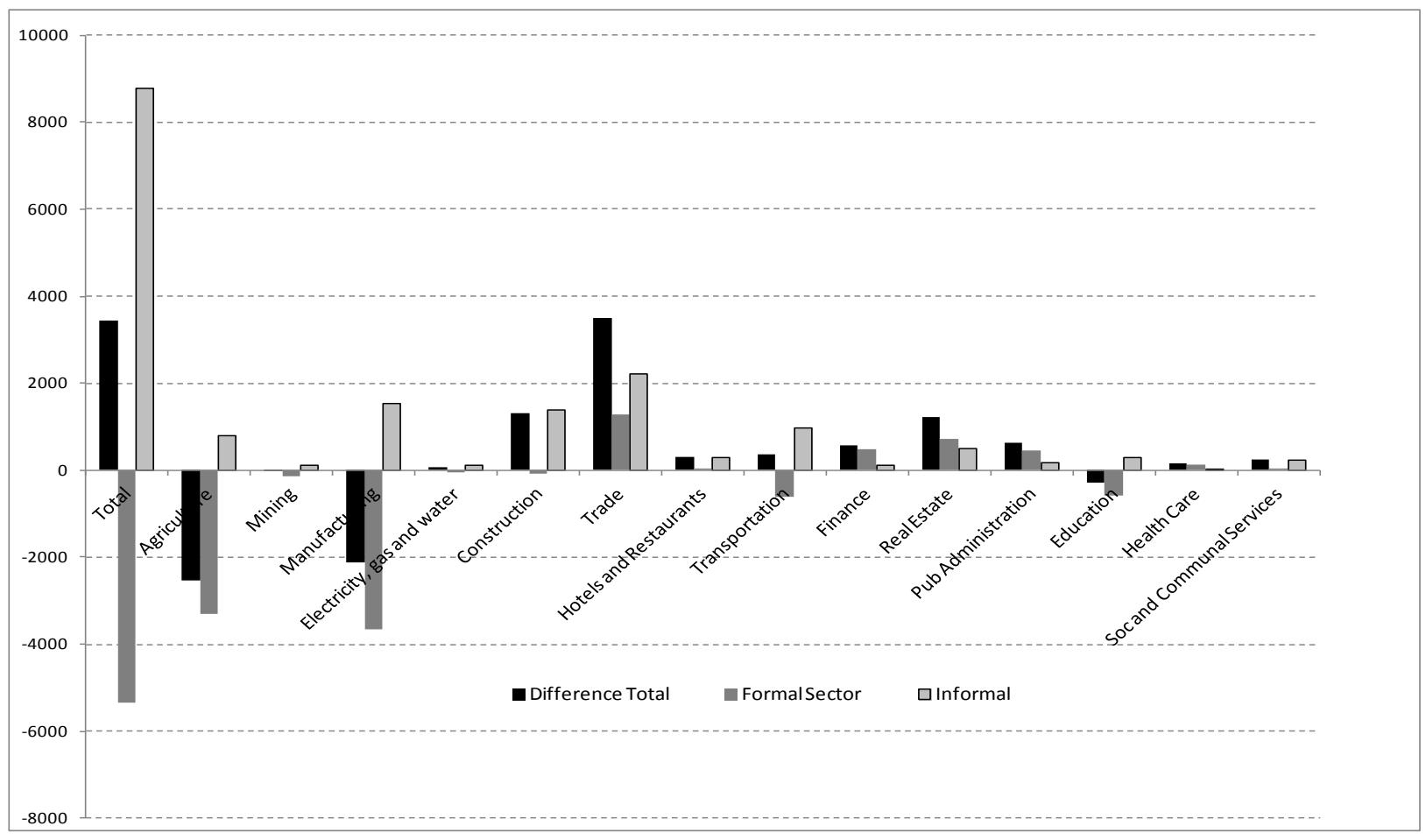

Source: Rosstat, the authors’ estimates 
Fig. 3. Evolution of informal employment, men, 1998-2010, RLMS

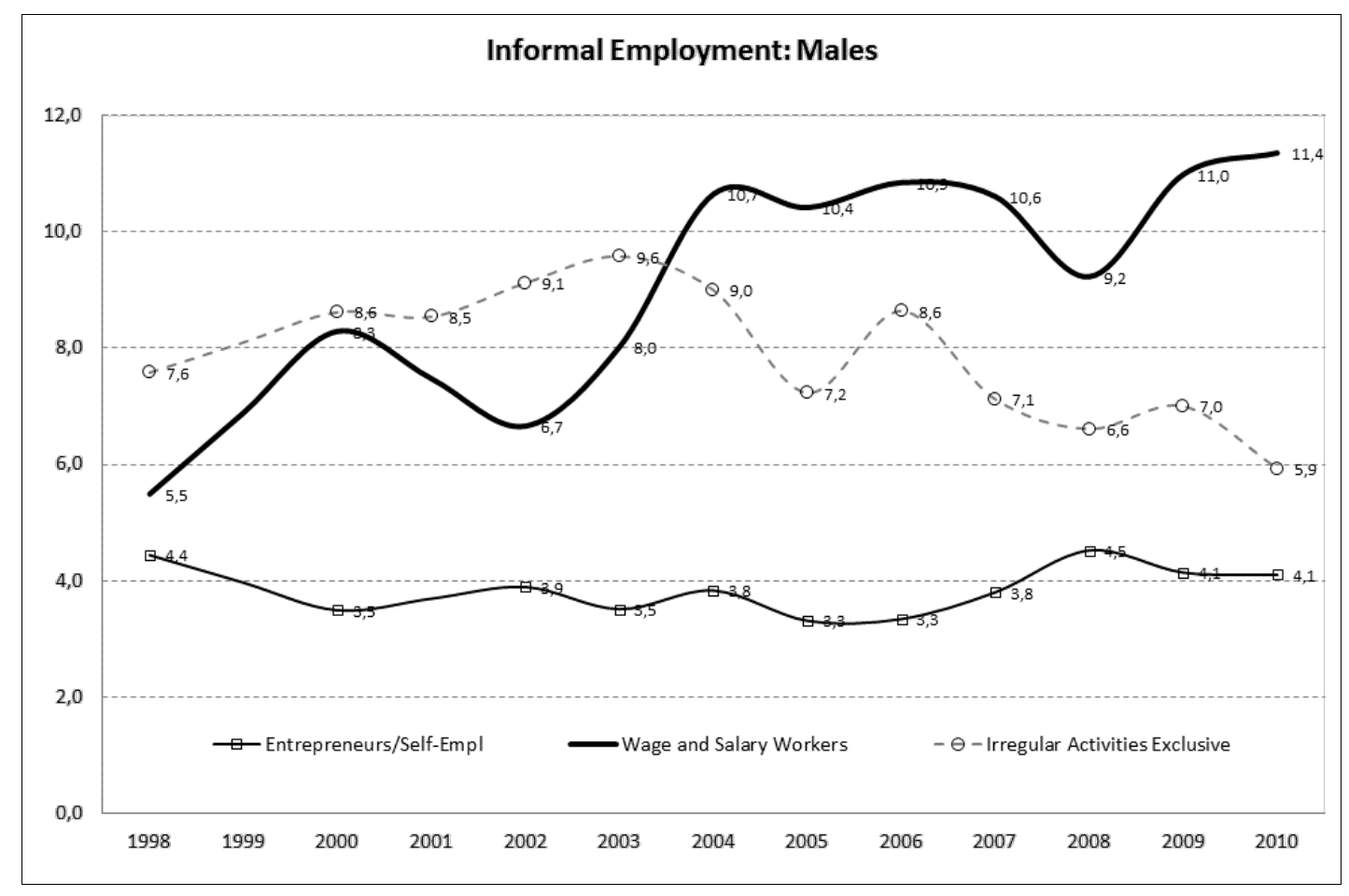

Source: RLMS, Gimpelson, Kapeliushnikov and Slonimczyk (2014)

Fig. 4. Evolution of informal employment, women, 1998-2010, RLMS

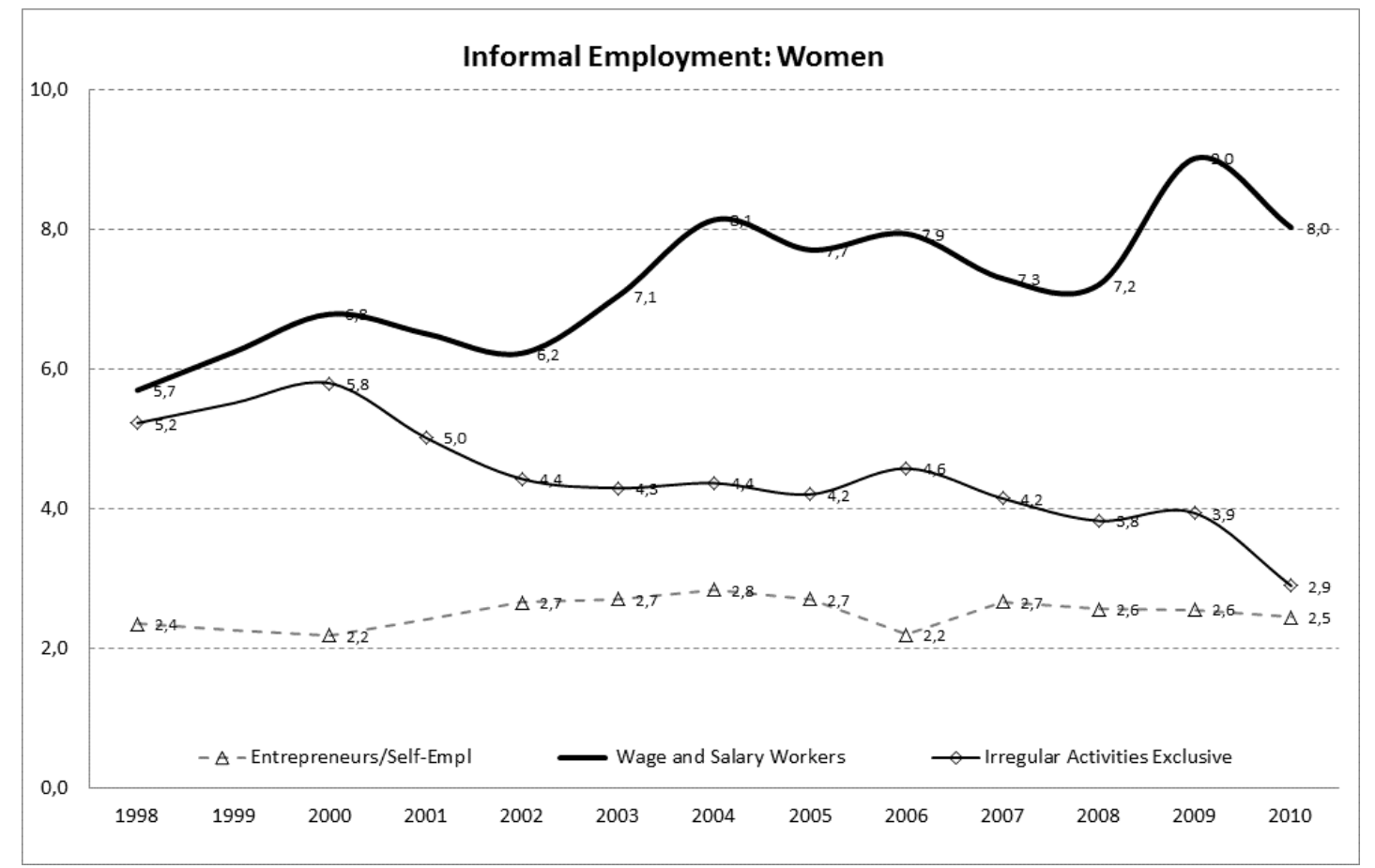

Source: RLMS, Gimpelson, Kapeliushnikov and Slonimczyk (2014) 
Fig 5. Evolution of earnings in formal and informal employment, men, 1998-2010, RLMS

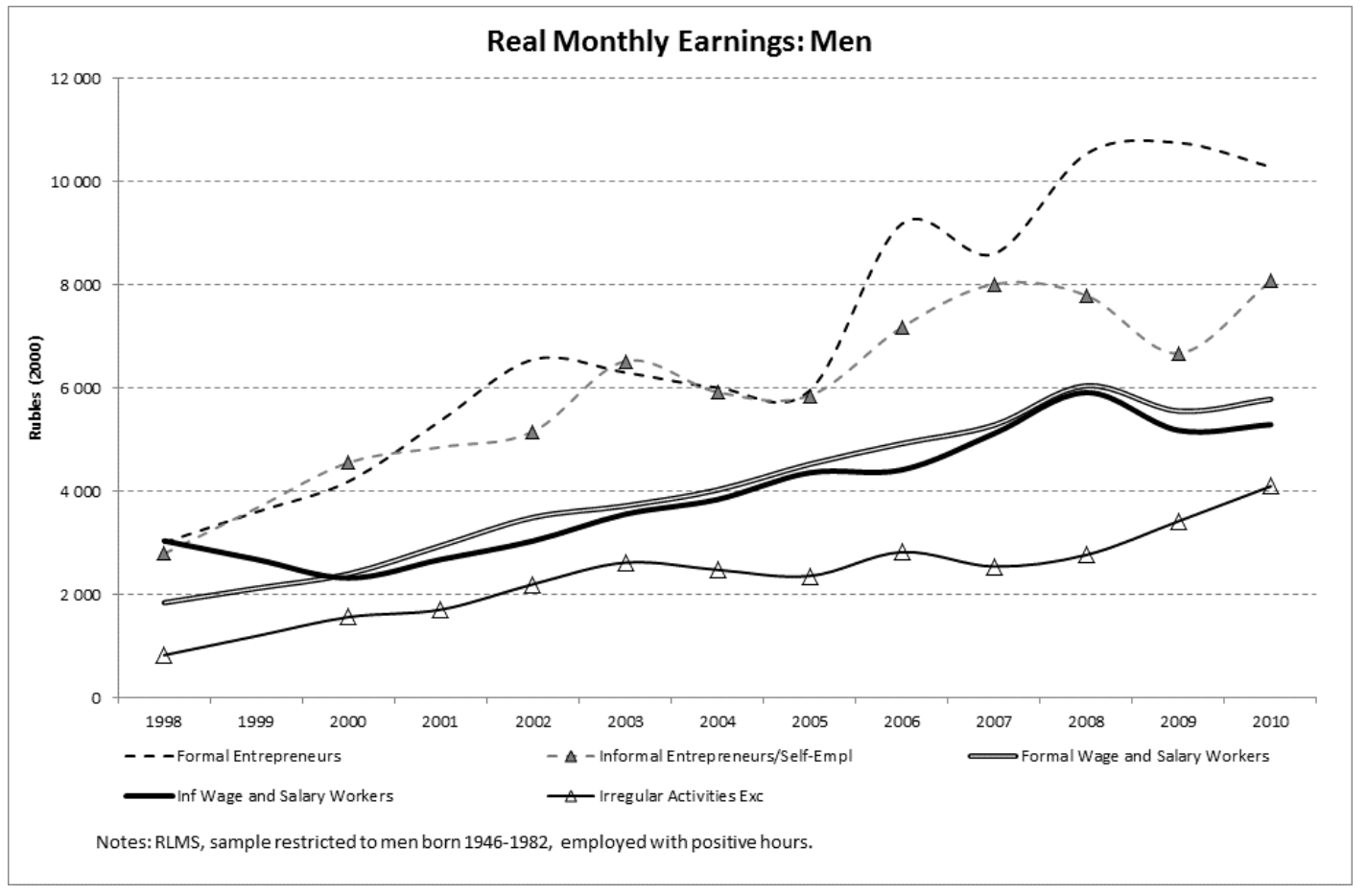

Source: RLMS, Gimpelson, Kapeliushnikov and Slonimczyk (2014)

Fig 6. Evolution of earnings in formal and informal employment, women, 1998-2010, RLMS

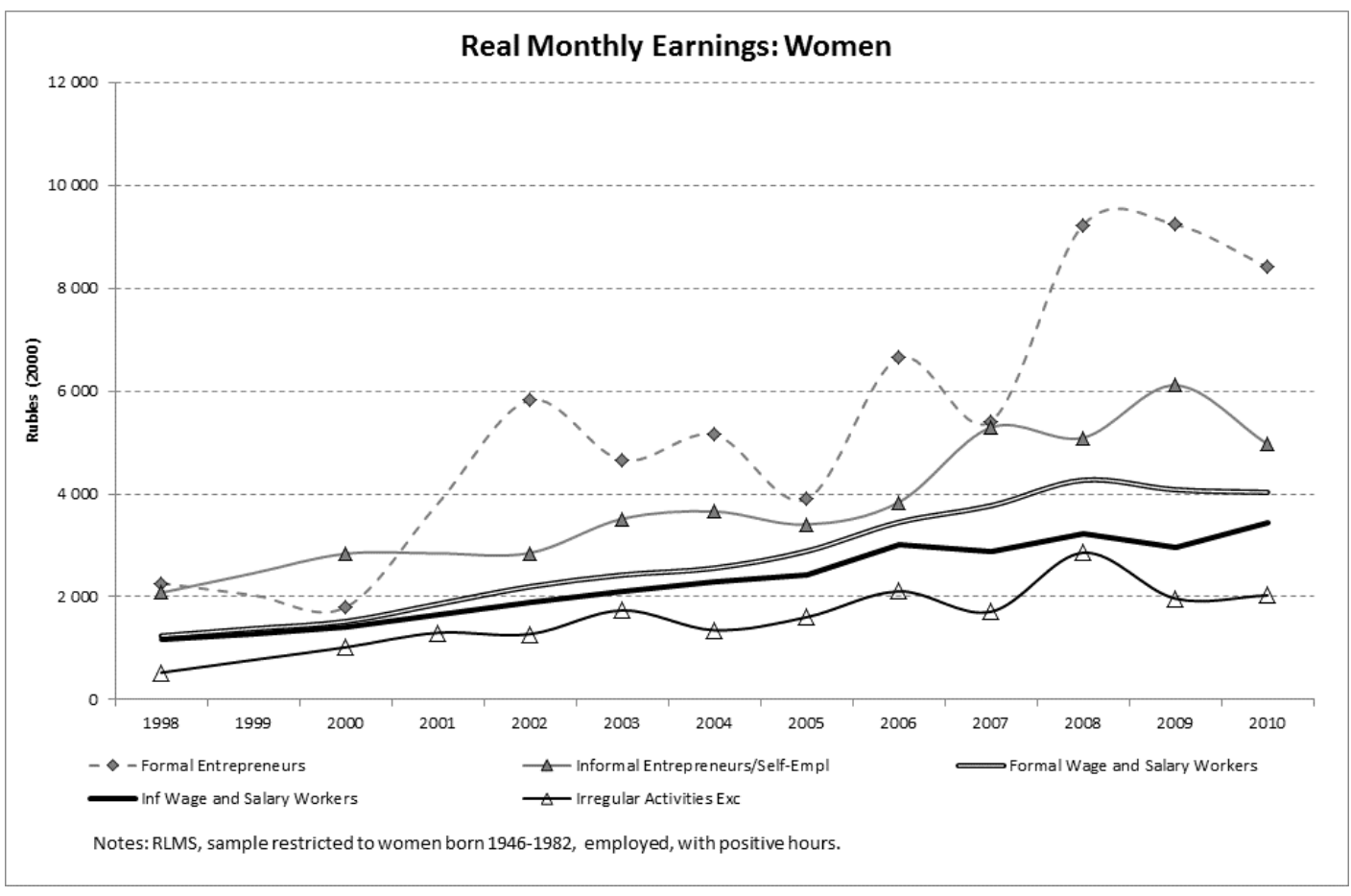

Source: RLMS, Gimpelson, Kapeliushnikov and Slonimczyk (2014) 
Table 1. Labor productivity, Value added per hour, (Rubles in constant 2008 prices, 2005-2011*

\begin{tabular}{ccccc}
\hline & \multicolumn{2}{c}{ Total economy } & \multicolumn{2}{c}{ Agriculture excluded } \\
\cline { 2 - 5 } & Formal sector & Informal sector & Formal sector & Informal sector \\
\hline 2005 & 263 & 63 & 272 & 95 \\
2006 & 281 & 67 & 291 & 103 \\
2007 & 301 & 68 & 312 & 108 \\
2008 & 319 & 65 & 330 & 99 \\
2009 & 305 & 69 & 315 & 105 \\
2010 & 316 & 66 & 328 & 103 \\
2011 & 326 & 67 & 337 & 106 \\
\hline
\end{tabular}

* based on the SNA data

Table 2. Incidence of Informality, 1998-2010

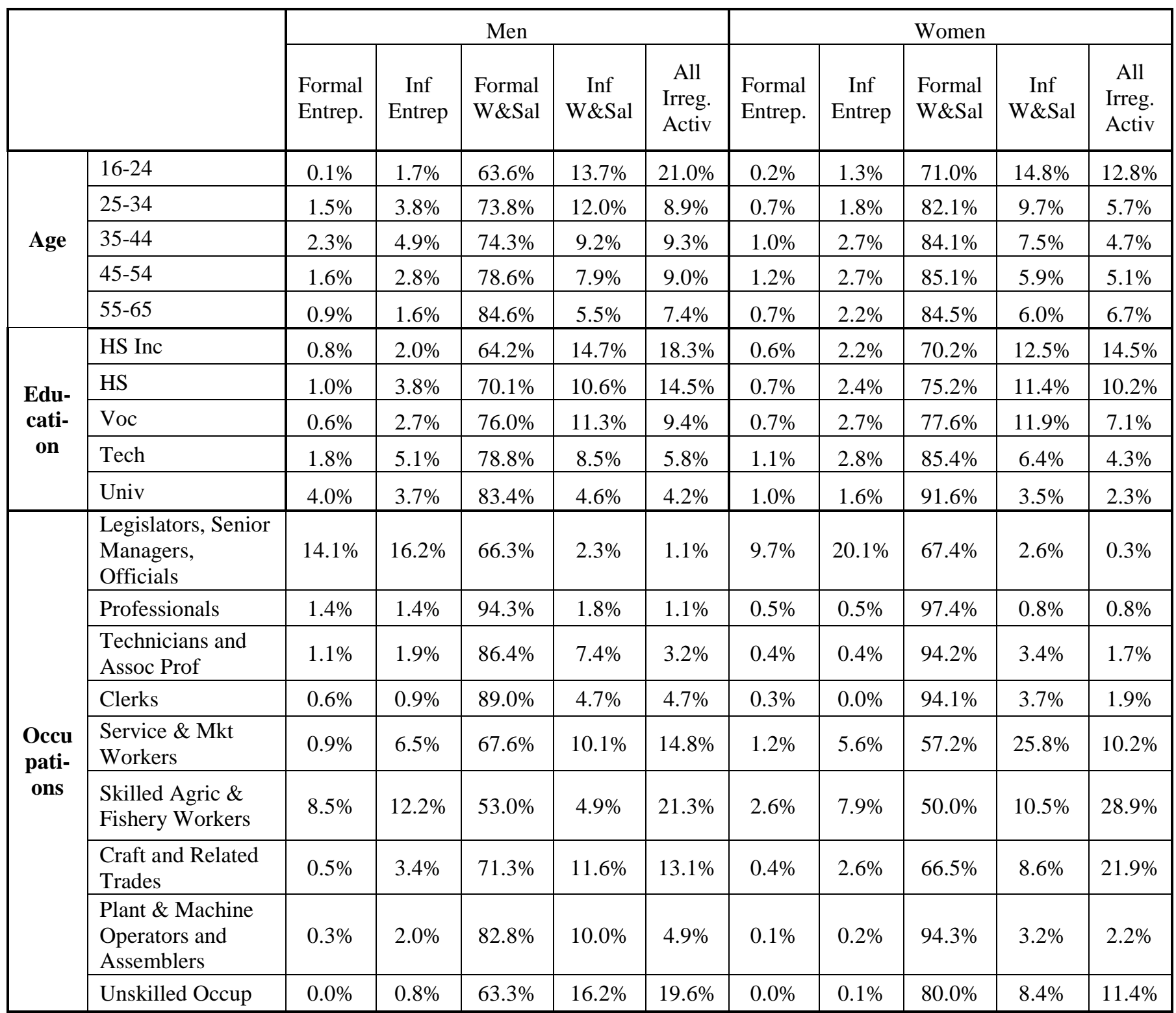

Source: RLMS, Gimpelson, Kapeliushnikov and Slonimczyk (2014) 
Table 3: Mobility in the Russian labor market (4 states), 2003-2010

\begin{tabular}{|lcccc|c|}
\hline \multicolumn{5}{|l|}{ TRANSITION PROBABILITIES: Pij } & \multicolumn{3}{l|}{} \\
\hline \multirow{4}{*}{ Formal } & Formal & Informal & Unemployed & Not in labor force & Pi. \\
Informal & $\mathbf{0 . 8 9 1}$ & 0.056 & 0.018 & 0.036 & 0.651 \\
Unemployed & 0.254 & $\mathbf{0 . 5 6 3}$ & 0.046 & 0.138 & 0.146 \\
Not in labor force & 0.304 & 0.221 & $\mathbf{0 . 1 8 6}$ & 0.289 & 0.038 \\
P.j & 0.106 & 0.125 & 0.057 & $\mathbf{0 . 7 1 1}$ & 0.166 \\
\cline { 2 - 5 } & 0.646 & 0.147 & 0.035 & 0.172 & \\
\hline & & & & \\
Average duration & Formal & Informal & Unemployed & Not in labor force \\
\hline
\end{tabular}

Source: RLMS, Gimpelson, Kapeliushnikov and Slonimczyk (2014)

Table 4: Mobility in Russian Labor Market (7 states), 2003-2010

\begin{tabular}{|c|c|c|c|c|c|c|c|c|}
\hline \multicolumn{9}{|c|}{ TRANSITION PROBABILITIES: Pij } \\
\hline & FS & IS & SEF & SEI & IA & $\mathrm{U}$ & NLF & Pi. \\
\hline Formal salaried & 0.890 & 0.034 & 0.003 & 0.004 & 0.015 & 0.018 & 0.036 & 0.640 \\
\hline Informal salaried & 0.333 & 0.448 & 0.009 & 0.038 & 0.058 & 0.037 & 0.078 & 0.066 \\
\hline Self-employed formal & 0.187 & 0.038 & 0.524 & 0.206 & 0.017 & 0.004 & 0.025 & 0.011 \\
\hline $\begin{array}{l}\text { Self-employed } \\
\text { informal }\end{array}$ & 0077 & م900 & 0116 & 0601 & 0057 & 0007 & 0032 & 0024 \\
\hline Irregular activity & 0.172 & 0.106 & 0.003 & 0.031 & 0.358 & 0.073 & 0.258 & 0.055 \\
\hline Unemployed & 0.302 & 0.090 & 0.002 & 0.012 & 0.119 & 0.186 & 0.289 & 0.038 \\
\hline Not in labor force & 0.105 & 0.037 & 0.001 & 0.006 & 0.082 & 0.057 & 0.711 & 0.166 \\
\hline P.j & 0.634 & 0.069 & 0.011 & 0.025 & 0.053 & 0.035 & 0.172 & \\
\hline & FS & IS & SEF & SEI & IA & $\mathrm{U}$ & $\mathrm{NLF}$ & \\
\hline Average duration & 9.1 & 1.8 & 2.1 & 2.6 & 1.6 & 1.2 & 3.5 & \\
\hline
\end{tabular}

Source: RLMS, Gimpelson, Kapeliushnikov and Slonimczyk (2014) 